\title{
INTERNATIONAL BUTTERFLY COUNTS - SASKATCHEWAN'S CONTRIBUTION AND THE BIRD CONNECTION
}

BERNIE GOLLOP, 2202 York Ave., Saskatoon, SK S7J 1J1

At age 98, the Audubon Society's Christmas Bird Count (CBC) has become the "world's largest citizen science program". ${ }^{2}$ In 1997 49,000 birders conducted 1800 CBCs. By comparison, the 24-year-old North American butterfly survey has to be considered the anonymous kid on the block. In 19973052 butterfly enthusiasts carried out 327 counts. Why a comparison between winter bird and summer butterfly counts? Because the latter is modeled on the former to the extent that both are conducted within a 24-km-diameter circle and take place within a 24-hour period.

The North American Butterfly Association coordinates the annual survey known as the 4th of July Count $(4 \mathrm{JC})$. Because butterflies are frustratingly more sensitive to environmental conditions than birds and because numbers peak at significantly different times between Florida and Alaska, the rules are flexible: these surveys may be done within a month of July 4th. Actually, in the southern US some are done in May and those in Mexico are often carried out between September and January. The purpose of the counts is 1) to have fun; and 2) to determine a) what species are present; b) how their numbers change from year to year and over the long-term, and c) why the changes occur - due to natural or man-made causes, e.g., early/late seasons or habitat destruction.
Ken Pivnick brought $4 \mathrm{JCs}$ to Saskatchewan. He started a series of counts at Pike Lake in 1986. Ron Hooper began his counts in 1990 at Fort Qu'Appelle. Mike and Bernie Gollop organized their first 4JC in 1993 in the Dundurn PFRA Community Pasture and had expanded to ten counts by 1998 . In 199711 of the 34 Canadian counts were in Saskatchewan - a total exceeded by only ten states and Ontario.

In 1997, the largest number of species on a $4 \mathrm{JC}$ was 154 in Mexico equivalent to almost the entire complement of Saskatchewan's 157 butterflies. In the United States, the highest individual counts were 102 species in Arizona and 101 in Colorado. Windsor, Ontario, held the Canadian record - 50 species, as did Cypress Hills Provincial Park for Saskatchewan - 39. The Cypress Hills count was higher than 260 others north of Mexico, including some in California, Arizona, New Mexico, Texas and Louisiana. By comparison a team of birders can find about 100 species on a 1-day June count around Saskatoon - largely because more than twice as many species of birds $(340 \pm$ ) have been found in southern Saskatchewan during our 4JC season.

In 1997 Saskatchewan 4JCs produced the highest North American counts for 11 species: Common Checkered Skipper: 81 at Matador (tied with a California count); Canadian Tiger 

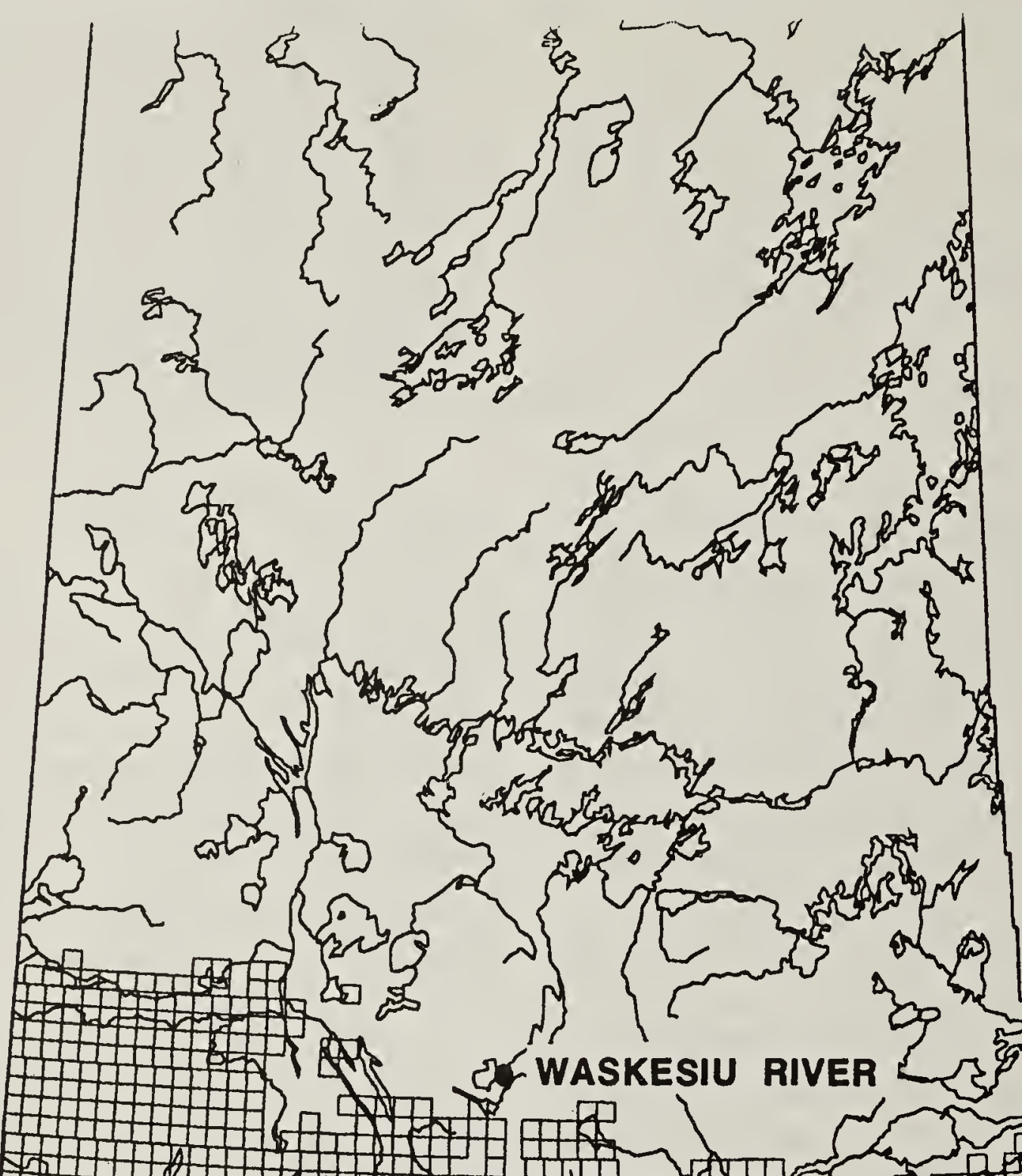
Af (1)

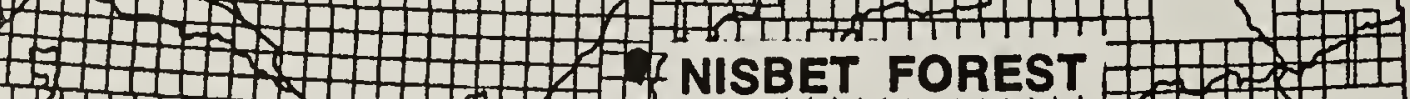

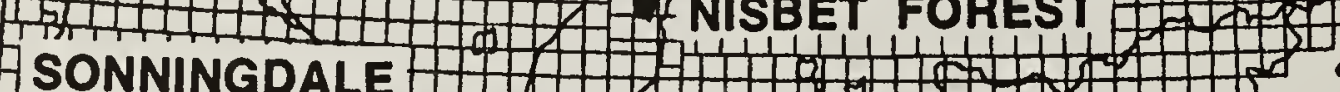
SONNINGDALE HHAH

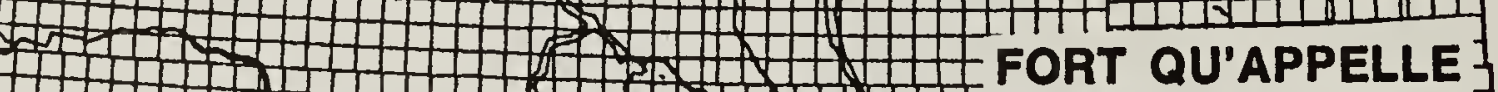

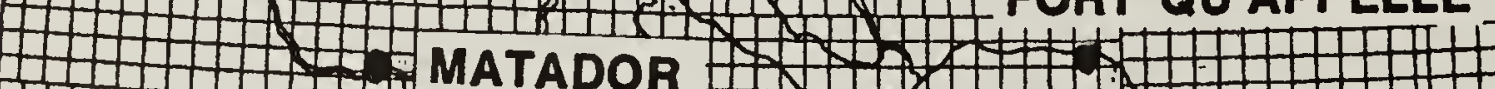

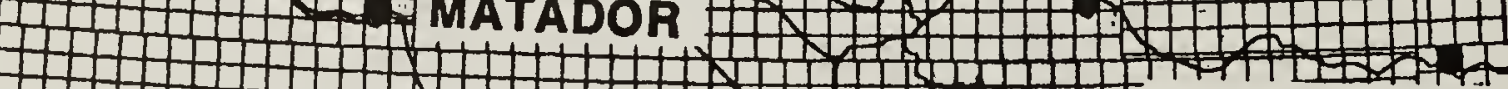

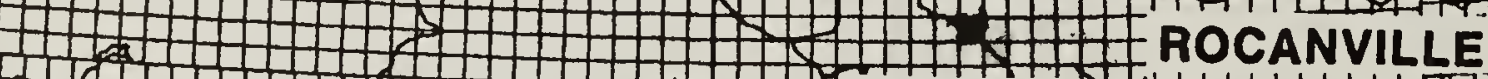
HAfHAH CYPRESS HILLS ZA

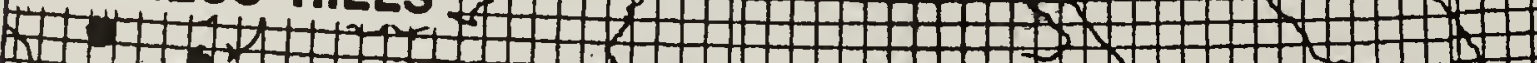
- EASTEND -

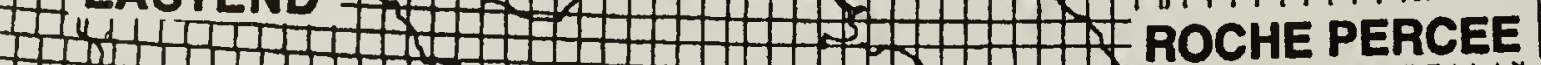




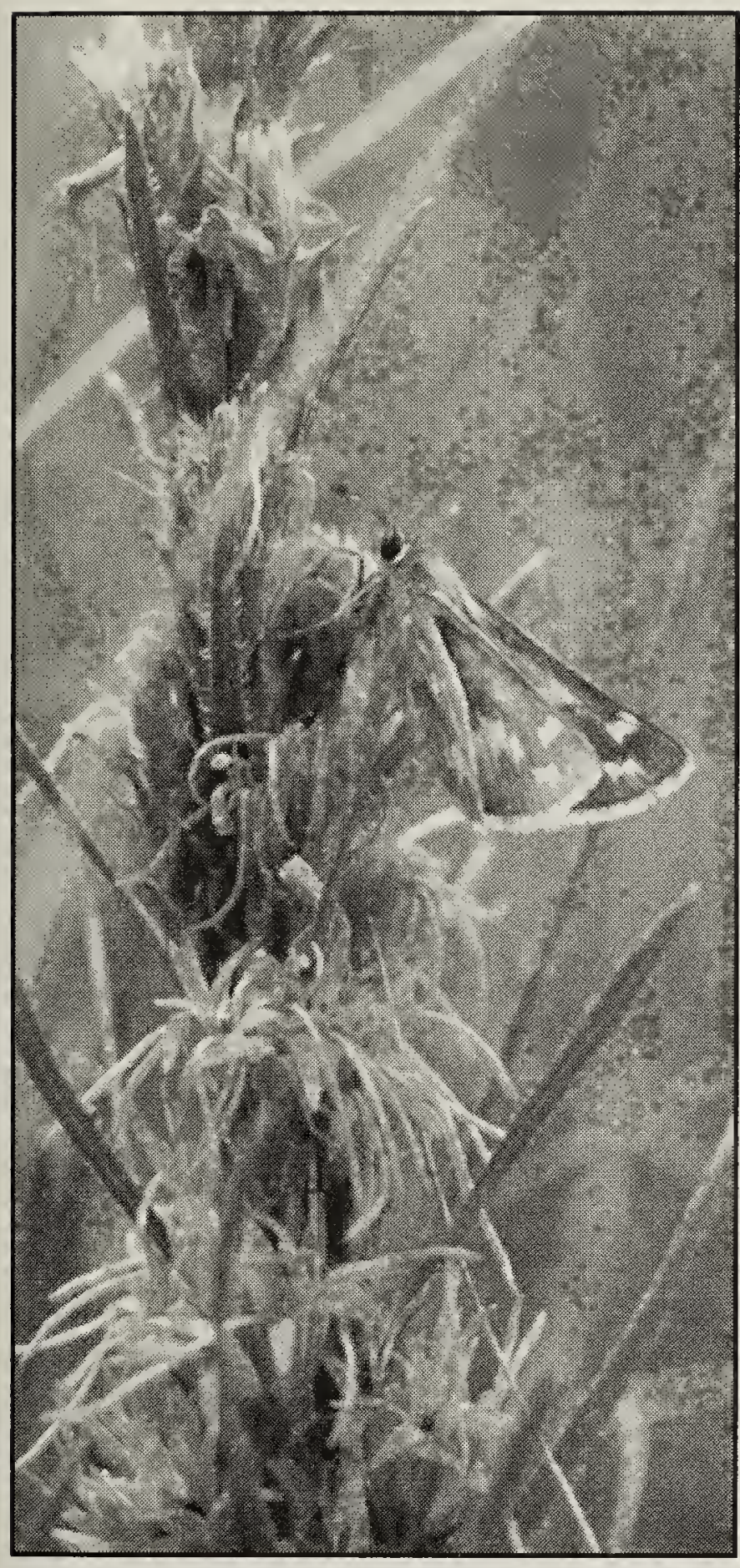

Plains Skipper, August 18, 1998 Bernie Gollop

Swallowtail: 125 at Sonningdale (a new continental high); Western White: 52 at Matador; Olympia Marble: 1 at Dundurn (the only North American record); Giant Sulphur: 10 at Cypress Hills (only N.A. record); Western Tailed Blue: 59 at Sonningdale; Zerene Fritillary: 46 at Cypress Hills; Arctic Fritillary: 104 at Nisbet Forest (only N.A. count); Sagebrush Checkerspot: 3 at Roche Percee (only N.A. record); Common Alpine: 101 at Cypress Hills; and Uhler's Arctic: 58 at Dundurn (new continental high).

In 199812 4JCs were conducted in the southern half of the province (south of $54^{\circ} 30^{\prime}$ ) between 8 June and 31 July by 39 count-participants, actually 21 people - some taking part in more than one count (see map and table). The total number of species was 80 , ranging from 14 at Regina to 45 in the Cypress Hills and averaging 25 per count. No species was seen on all 12 counts. One was found on 11 counts - White Admiral and five on ten counts - Canadian Tiger Swallowtail, Clouded Sulphur, Melissa and Greenish blues, and Northern Crescent.

At the other end of the scale, eight $4 \mathrm{JCs}$ accounted for the 31 species found only once: Cypress Hills had 10 single-count species: 1 Afranius Duskywing, 1 Draco Skipper, 4 Margined and 1 Mustard white, 25 Large Marbles, 6 Pink-edged Sulphurs, 1 Western Pine Elfin, 7 Boisduval's Blues, 6 Zerene Fritillaries and 102 Variable Checkerspots; Waskesiu River had 7: 32 Dreamy Duskywings, 3 Old World Swallowtails, 32 Eastern Pine Elfins, 9 Spring Azures, 1 Frigga and 1 Freija Fritillary and 1 Gray Comma; Nisbet Forest had 5: 4 Dorcas Coppers, 11 Coral Hairstreaks, 10 Aphrodite, 12 Atlantis and 107 Arctic Fritillaries; Roche Percee had 3: 1 Delaware Skipper, 23 Sagebrush Checkerspots and 1 Eastern Comma; Fort Qu'Appelle had an Uncas Skipper and an Acmon Blue; Rocanville had 2 Striped Hairstreaks and 9 Little Wood-Satyrs; Eastend had 2 Ruddy Coppers, and Matador had a Nevada Skipper. While many cases of uniqueness are due to a species' range, for some wide-ranging butterflies they are due to their flight periods, e.g., Coral Hairstreak, Aphrodite Fritillary and Gray Comma. Some occurrences or lack thereof are due to the luck of the day.

If these counts had been for birds, several species would have appeared on every one because some 91 breeding birds, all of which are with us 


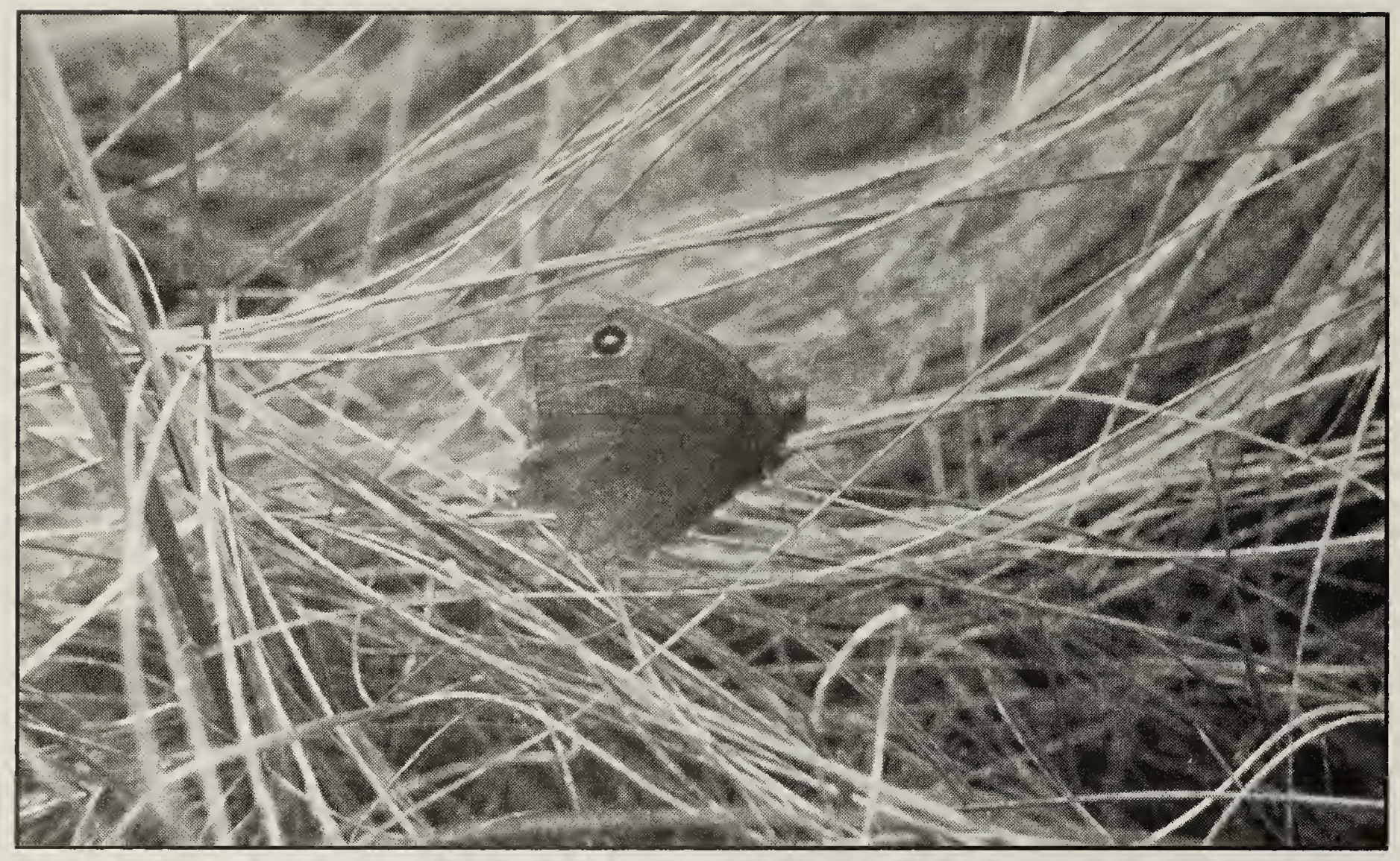

Common Wood-Nymph, August 8, 1998

Bernie Gollop

throughout the period, have ranges that include all 12 4JCs. However, on average, butterfly ranges in southern Saskatchewan are smaller than birds'. The 12 counts were completely within the distributions of only 39 species of butterflies of which, at most, 23 are normally flying through all of the 2 -month period.

The total number of individuals was 5534 , which works out to an average of 461 butterflies per count - about one fifth the number of birds for a one-day spring count by one team. The most commonly identified species were Clouded Sulphur (793), Northern Crescent (419), Common Wood-Nymph (285), Canadian Tiger Swallowtail (278) and Greenish Blue (231). Twelve species were represented on only one count (see above). Fewer Monarchs (below the normal number) came to Saskatchewan in $1998-2$ were seen on these counts, compared to last year's above-average 21.

Partly because they do not identify themselves by song, proportionately more butterflies than birds are difficult to identify to species in the field. As a result, some 4JCs have a significant number of identifications only to genus, subfamily and family. In 1998, these accounted for more than 1 butterfly in five (1207 individuals) of the butterflies seen. Over a third (460) of these were recorded as "Blues" - more than the 429 blues identified to 8 species. For the Ft. Qu'Appelle and Regina counts, only butterflies identified to species are reported.

As with similar bird surveys, the best available unit for comparing one area or year with another is probably animals per party-hour. Party-hour is a measure of the effort involved in searching, i.e., the number of hours that groups whether of one or 5 or 20 butterfliers spend separately looking for their quarry. On this basis, Cypress Hills Provincial Park was number one in Saskatchewan with 83 butterflies per party-hour, down from 107 in 1997 . It was followed by Roche Percee with 65 in 1998, up from 42. The lowest numbers were 13 at Dundurn (55 in 1997) and 18 at Ft. 
Qu'Appelle (28). The reason for such variations is most often weather, either on count day or in the previous month or two - being favourable or unfavourable to butterfly development.

Because a species' flight period is so short, less than a month in some cases, things happen fast; hence the need for counts at the same time each year. Calendar date has to suffice because of the difficulty of assessing how much earlier or later one year is than another. From 1995 through 1998, Saskatoon 4JCs were held on 12, 14, 12 and 11 July. In 1996 Common Wood-Nymphs were particularly late. The comparison with other years is based, in part, on an almost daily count of butterflies on the Central Avenue Prairie in Saskatoon in 1994 when the period between first appearance and the peak number of wood-nymphs (147 in 1 hour) was 2 weeks. ${ }^{1}$ It would appear that 1995, 1997 and 1998 were similar in relation to wood-nymph development around Saskatoon and about 11 days earlier than 1996.

During these 4JCs, copulating pairs of butterflies were also recorded: 2 pairs each of Clouded Sulphur at Saskatoon, Silvery Blue at Eastend and Great Spangled Fritillary at Roche Percee.

The 1998 participants were: Mike and Bernie Gollop for Dundurn, Matador, Rocanville, Roche Percee and Sonningdale; Mel Fitch and the Gollops at Cypress Hills and Eastend; Ross Layberry and the Gollops at Nisbet Forest; Keith Roney, Keith Barr, Jane Chapco, Bob and Sandy Ewart, Ron Hooper, Jeanette Pepper, Jim Rydzik and Glenn Sutter at Regina; Ron Hooper, Phyllis Bordass and Keith Stephens at Fort Qu'Appelle; Alex Fornal-Gollop, Lorriene, Craig, Andy and Rob Salisbury, Michael Williams and the Gollops at Saskatoon.
So, how does one count butterflies? A survey is best done between 8 am and $5 \mathrm{pm}$, because most butterflies fly from several hours after sunrise to the same period before sunset. Warm, sunny days with little wind will usually be most productive. At the extremes of our butterfly season - 13 March and 3 November - the Mourning Cloak is all alone but more than $80 \%$ of our species fly in parts of both June and July.

There may be three to ten stops within a count circle, each with one or more routes radiating from it.

Walking the same trails each year, observers try to keep track of each butterfly seen and use their best judgment in counting an individual once and only once. The party-hour rates above show that this is not as impossible a feat as it might first seem. Two butterflies per minute is a high average;

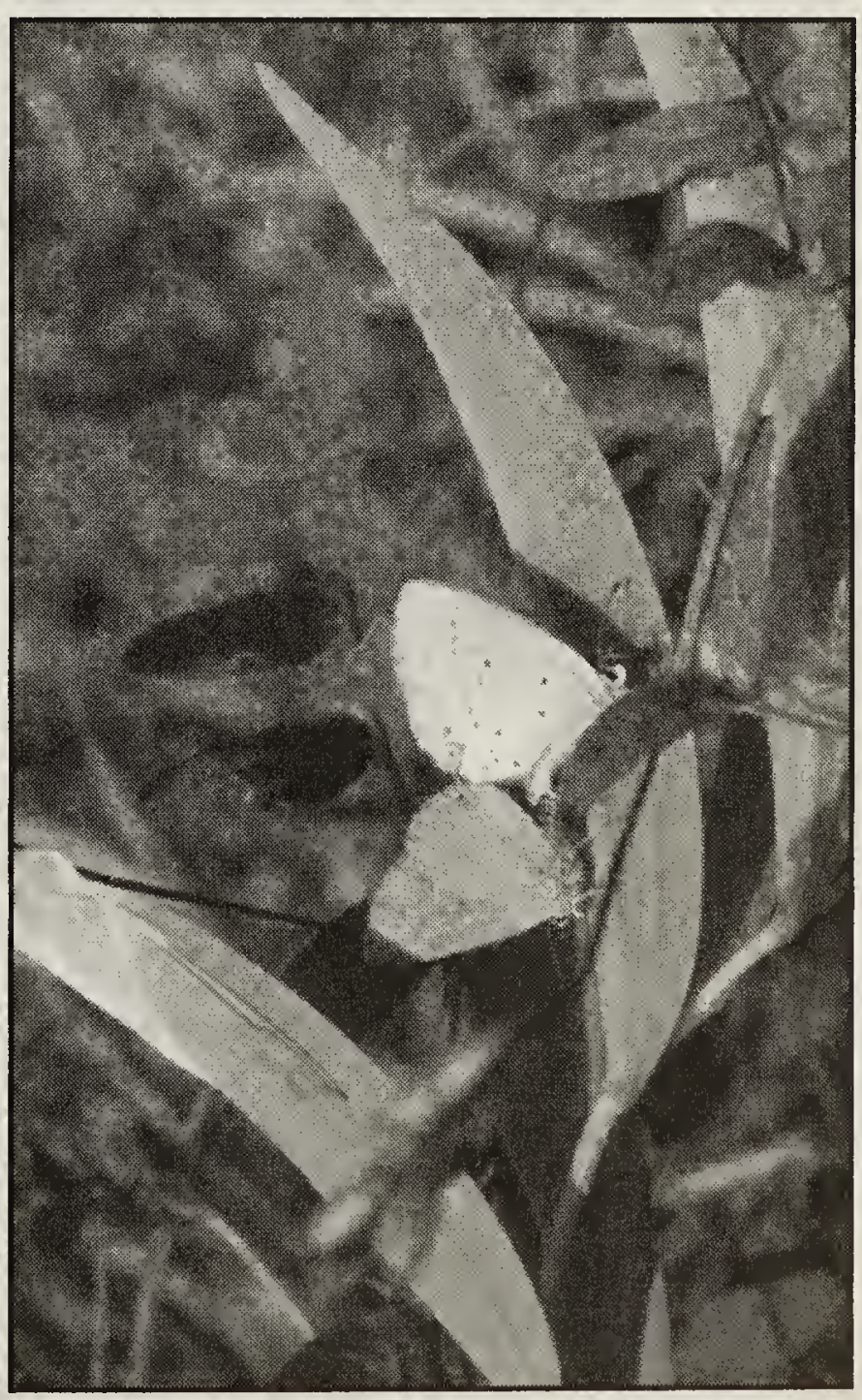

Western Tailed Blue pair, June 21, 1998 Bernie Gollop 


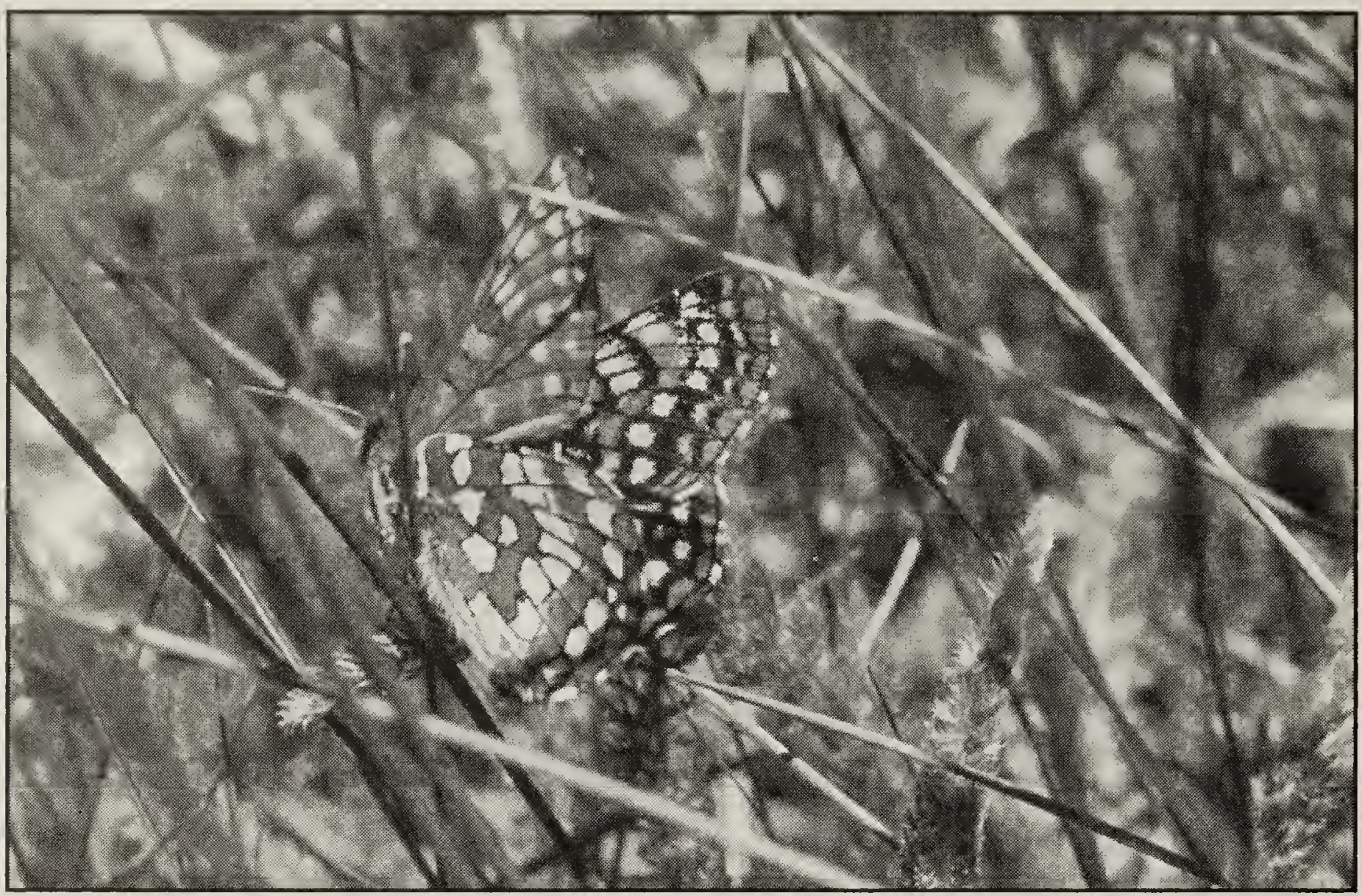

Variable Checkerspot, 16 June 97, Sucker Creek

Bernie Gollop

some sites average only one in 3-4 minutes. Observations are recorded in a field book or on a form, along with information affecting the count: percent of sun, temperature and wind morning and afternoon (because fewer butterflies fly on overcast, hot or cold or windy days). During a shower, the count shuts down. Binoculars, preferably focusing down to $2 \mathrm{~m}$, are a big help.

So, if the birders who have read this article want to enhance their life style, butterflies are obviously the way to go. Field trips require none of the birder's early morning rising and freezing or binocularizing in the rain. The Audubon Society Handbook for Butterfly Watchers by Robert Pyle (1984. Scribner's, New York) outlines all the pleasures you can expect and how to attain them. The best book for identification is The Butterflies of Canada by Layberry, Hall and Lafontaine. (1998. UT Press, Toronto. $\$ 29.95)$. A checklist with flight periods, geographical distribution, seven local lists and other information will be available from me, hopefully in May 1999 (free). You might also want a net (children's size is what I use) for closer, more leisurely, but careful examination of these fascinating, fragile, flying flowers.

My thanks to Anna Leighton, Mike Gollop and Mary Gilliland for editing various versions of this article.

1. GOLLOP, BERNIE. 1995. The fascinating fescue. Blue Jay Vol. 53: 189-196.

2. NATIONAL AUDUBON SOCIETY. 1998. The 98th Christmas Bird Count. American Birds. 610 pages. 


\begin{tabular}{|c|c|c|c|c|c|c|c|c|c|c|c|}
\hline 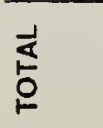 & 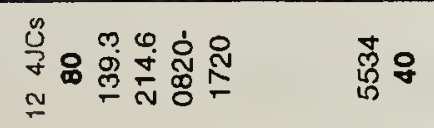 & న⿻ & $\tilde{m}-N$ & $\mid \begin{array}{l}5 \\
+\end{array}$ & $\underline{\infty}-0$ & -+ & $\simeq \stackrel{n}{-}-$ & $+\stackrel{\infty}{\circ}$ ले & $-\infty \stackrel{\infty}{\mathrm{N}}$ & $\hat{0} \stackrel{\bar{\infty}}{+}+$ & $-\frac{0}{7} \stackrel{2}{\infty}$ \\
\hline 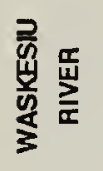 & 产 & $\because 2$ & $\widetilde{m}$ & 9 & & & & $-\stackrel{20}{2}$ & $\infty \infty$ & & \\
\hline 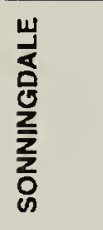 & 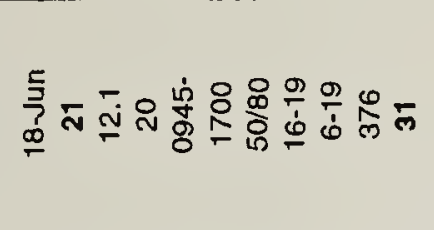 & $\stackrel{2}{9}$ & & & - & & N & - & -8 & $\infty$ & \\
\hline 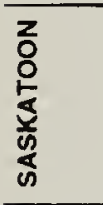 & 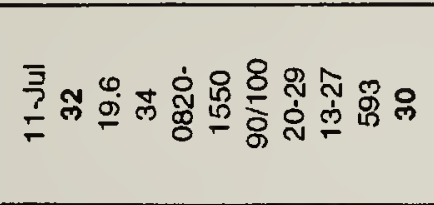 & v & & & $\sigma$ & $\infty$ & $=N$ & N & - & $=N$ & 8 \\
\hline 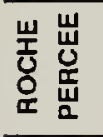 & 预 N & N & & $m$ & & & - & N & & $\pm \infty$ & $\stackrel{9}{\circ}$ \\
\hline 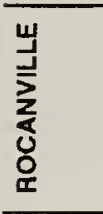 & 亞 & N & & $\infty$ & & & $-\infty$ & N & & $1-$ & - \\
\hline & 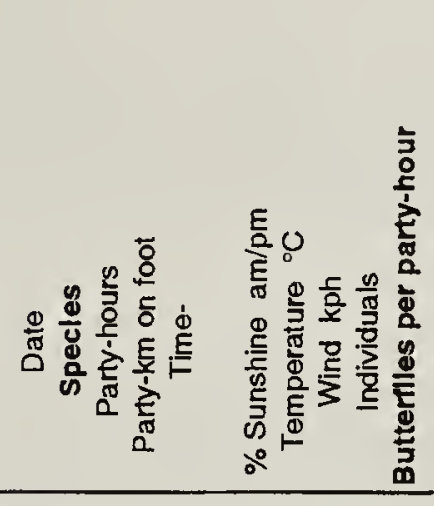 & 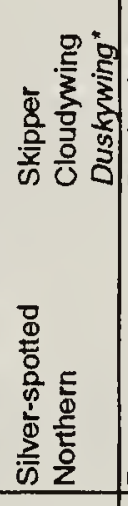 & 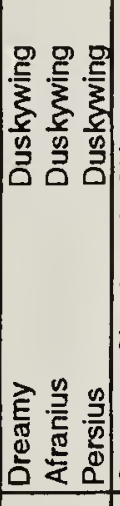 & 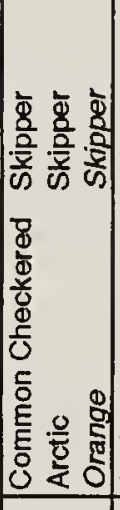 & 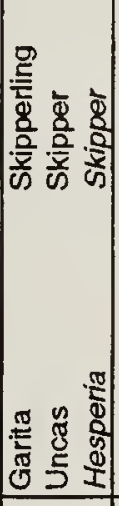 & 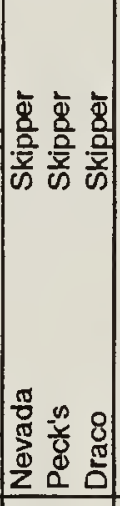 & 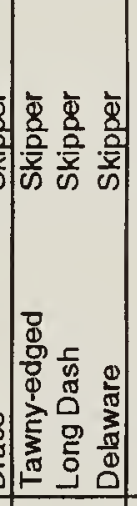 & 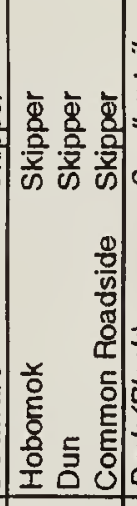 & 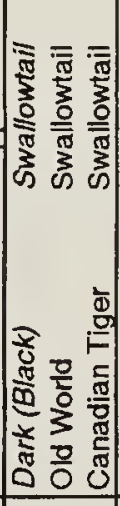 & 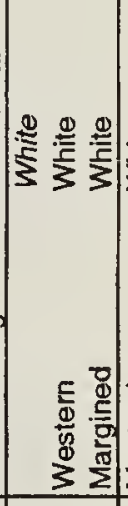 & 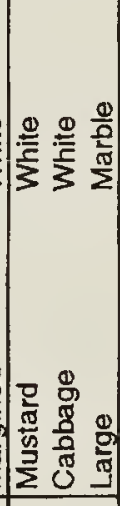 \\
\hline 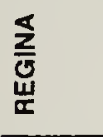 & 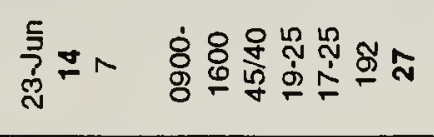 & & & & g & & & & क) & & מ \\
\hline 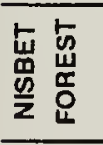 & 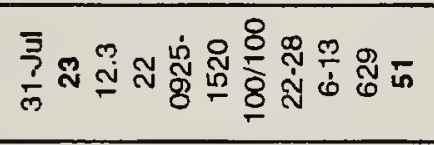 & & & & & & & 0 & & $\infty$ & N \\
\hline 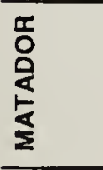 & 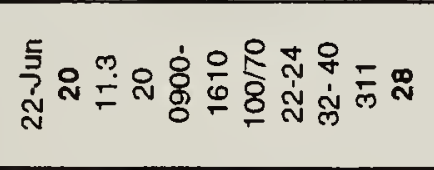 & -8 & & ๓్ & $N$ & - & & - & - & $-\frac{9}{4}$ & $\stackrel{N}{N}$ \\
\hline t㞾 & 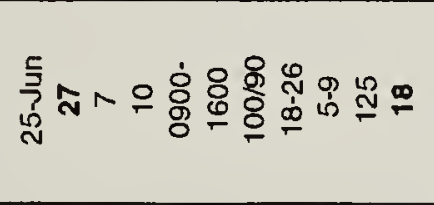 & - & & N & $=-$ & & $\sim$ & $\infty \quad-$ & $\nabla$ & & $\nabla$ \\
\hline & 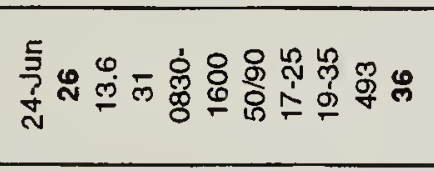 & $\nabla$ & & 으 & ₹ & & & - & $\infty$ & $\stackrel{2}{\longleftarrow}$ & $\infty$ \\
\hline 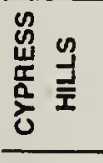 & 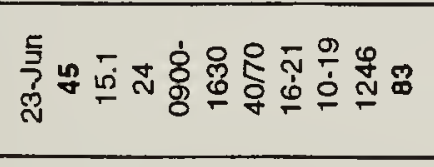 & -00 & -0 & & $\sim \approx$ & -- & N & - & 음 & $\begin{array}{lll}10 & 0 & 0\end{array}$ & $\stackrel{\infty}{N}$ \\
\hline 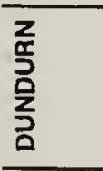 & 产 & & & - & - & & & $N$ & $\stackrel{\Delta}{N}$ & $-\infty$ & - \\
\hline
\end{tabular}




\begin{tabular}{|c|c|c|c|c|c|c|c|c|c|c|c|c|c|c|c|}
\hline 京 & 욧 & $\forall 0 N$ & $\forall \operatorname{~LO~}=$ & N ले - & $\mathscr{F}-R$ & 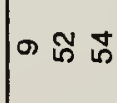 & $\bar{N} \wedge-$ & in ह్ల & $\frac{6}{=}$ 우 0 & 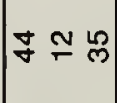 & $\simeq$ 两 & $\infty$ & $|\hat{0}+\stackrel{\Omega}{N}|$ & $\frac{\infty}{2} \stackrel{\frac{9}{7}}{7}$ & ๑ 을 = \\
\hline 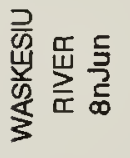 & & & & స్ల & $0 \quad \mathrm{~N}$ & a & $\sim$ & & & & & -- & & $m \infty$ & $m$ \\
\hline 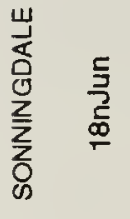 & $m \nabla$ & N & & & $8=$ & $\stackrel{9}{\circ} \mathrm{N}$ & ग्ले & $\approx$ & & N & & 0 & & $2 \quad 8$ & \\
\hline 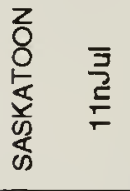 & 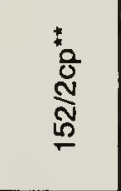 & & & & $\infty$ & $\nabla r$ & 8 & $-\infty$ & กิ & N 으 & 60 & in & $\tau$ & $\approx$ & \\
\hline 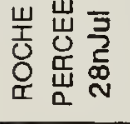 & $\underset{\sim ్ n}{n}-$ & & & & N & $\nabla$ & & $\hat{\mathrm{N}}-$ & 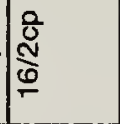 & N $\quad-$ & & & $\stackrel{\text { N }}{1}$ & के $\nabla \nabla$ & - \\
\hline 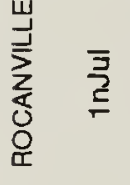 & - & & & IN & is $m$ & & 1 & ஜ - & $\nabla$ & 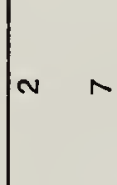 & & & & 용 & N \\
\hline$\frac{\Phi}{\pi}$ & 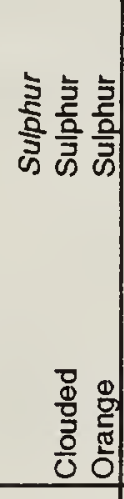 & 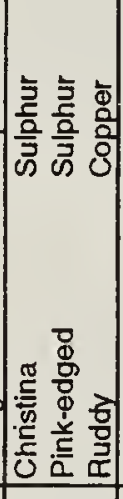 & 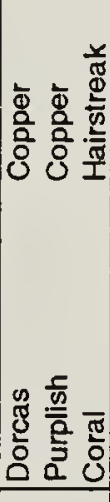 & 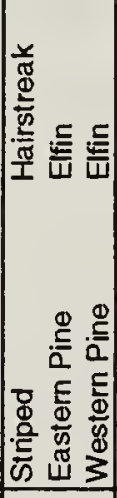 & 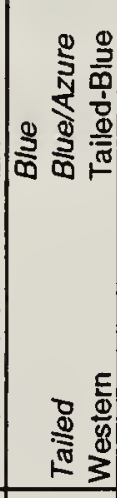 & 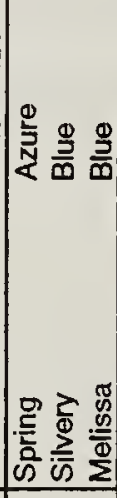 & 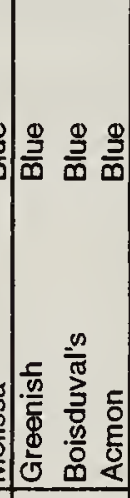 & 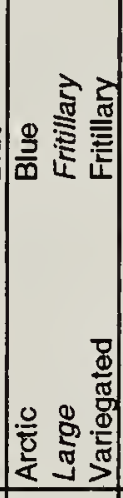 & 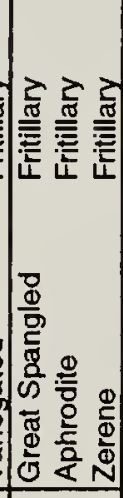 & 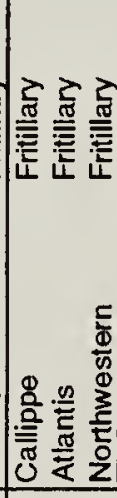 & 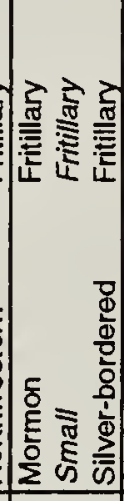 & 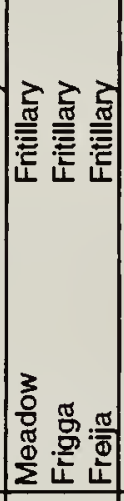 & 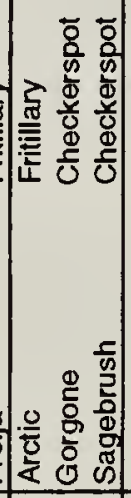 & 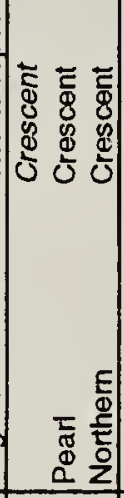 & 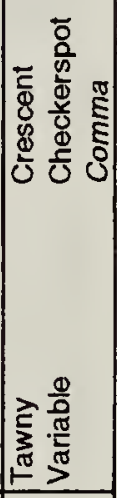 \\
\hline 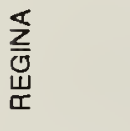 & 으 & & & & & $\wedge$ L & 0 & & & $r$ & & & & $r$ & \\
\hline 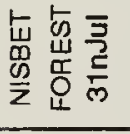 & $\stackrel{N}{N}$ & & $\nabla-F$ & & -2 & - & & $\stackrel{8}{2}$ & 웅 으 & $\simeq \infty$ & 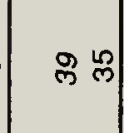 & $\infty$ & 10 & $\begin{array}{ll}\hat{\sim} & 0\end{array}$ & - \\
\hline 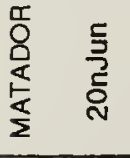 & & & N & & 1 & $\stackrel{\infty}{\sim}$ & 0 & $\infty$ & $N$ & 10 & $\nabla$ & & & - & \\
\hline 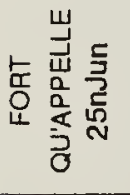 & $\nabla N$ & - & $r$ & & $N$ & $\infty$ is & & & & $a$ & & & & ) & 0 \\
\hline 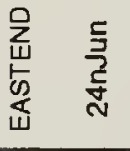 & $2 N$ & & & & $\$$ & 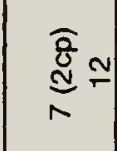 & న్ల & -87 & $n$ & 0 & & & & $m$ & \\
\hline 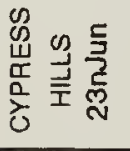 & $\hat{N} \sigma$ & $-\infty$ & - & & 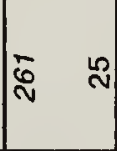 & $\infty m$ & $\left.\right|^{\frac{6}{6}}$ & $-\infty-$ & $\bullet$ & $\nabla \quad N$ & $\infty 0$ & 8 & - & 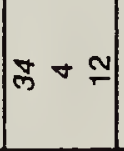 & -8 \\
\hline 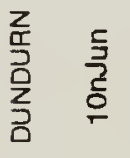 & $\sim \pm$ & & & & $\approx m$ & $\nabla m$ & $\stackrel{\text { N }}{2}$ & N & & & $m$ & & $N$ & - & \\
\hline
\end{tabular}




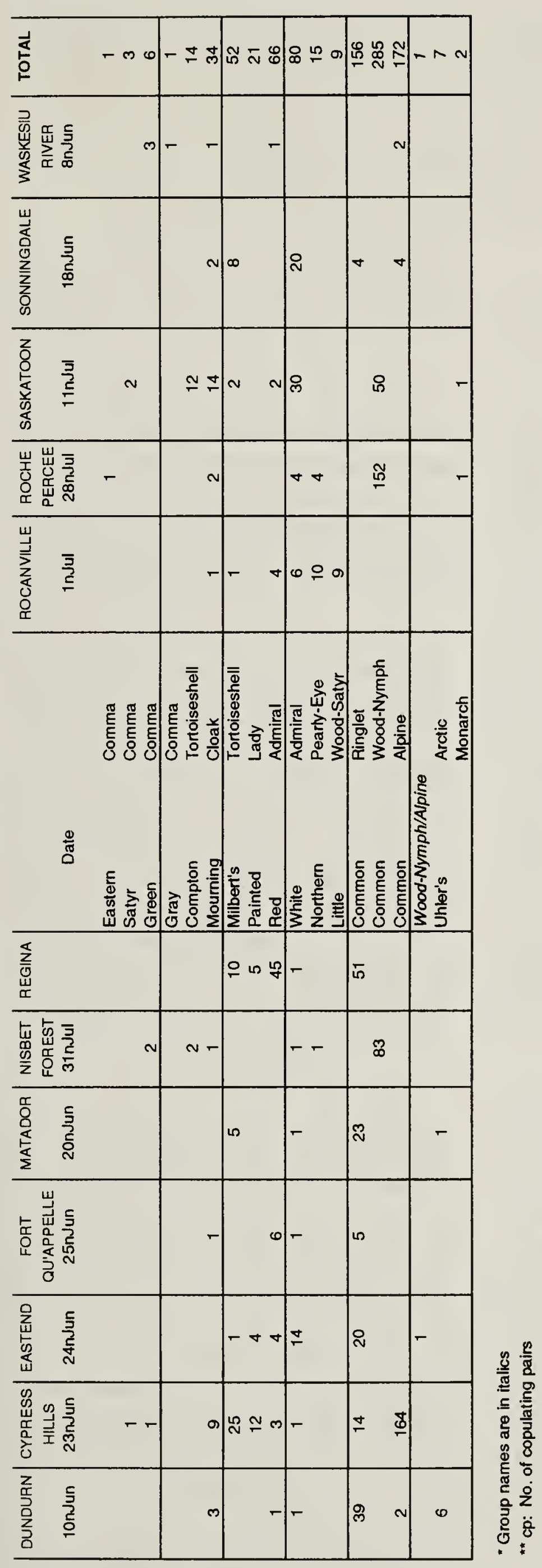

